\title{
A Case of Swyer Syndrome
}

\author{
Soon Il Jung, Hee Soon Cho, Chae Hoon Lee, Kyung Dong Kim \\ Department of Laboratory Medicine, \\ College of Medicine, Yeungnam University, Daegu, Korea
}

-Abstract-

46,XY pure gonadal dysgenesis is a sex-reversal disorder, that is characterized by the presence of a female phenotype, with a normal to tall stature, primary amenorrhea and sexual infantilism. The internal genitalia are female with a uterus and vagina being present, however, there are bilateral dysgenetic gonads. In addition, neoplasia occurs in 20 30\% of patients who have gonadal dysgenesis and a Y chromosome. A 34 year old woman presented to our hospital with the chief complaint of primary amenorrhea. Physical examination revealed no secondary sexual characteristics and no somatic abnormality. Peripheral blood karyotype was 46,XY, and polymerase chain reaction (PCR) for the Sex determining Region Y (SRY) gene was positive. Sequencing analysis of the SRY gene revealed a single nucleotide polymorphism. A laparoscopic gonadectomy was performed to remove both gonads, and no tumor cells were observed. Estrogen replacement therapy was instituted.

Key Words : Swyer syndrome, SRY gene, Gonadal dysgenesis

Introduction

46,XY pure gonadal dysgenesis, also known as Swyer syndrome, is an uncommon disorder of sexual differentiation that is characterized by the presence of a female phenotype, primary amenorrhea, sexual infantilism and bilateral streak gonads without the somatic abnormality of Tuner's syndrome. ${ }^{1)}$ This condition may occur sporadically or be inherited as an autosomal recessive trait or be inherited as an $\mathrm{X}$-linked trait in XY gonadal dysgenesis. ${ }^{2}$ As many as $20 \sim 30 \%$ of patients with this condition are at the risk for the formation of gonadal tumors, therefore patients should undergo

책임저자 : 조희순, 대구광역시 남구 대명동 317-1, 영남대학교 의과대학 진단검사의학교실

Tel: (053) 620-3633, Fax: (053) 653-7774, E-mail: chscp@med.yu.ac,kr 
- Soon Il Jung $\cdot$ Hee Soon Cho $\cdot$ Chae Hoon Lee $\cdot$ Kyung Dong Kim -

Table 1. Sequences of primers using polymerase chain reaction and direct sequencing of the SRY gene

\begin{tabular}{clc}
\hline & \multicolumn{1}{c}{ Primer sequences } & Size of products \\
\hline Forward primer & $5^{\prime}-$ TTTCGAACTCTGGCACCTTT-3' & \multirow{2}{*}{$739 \mathrm{bp}$} \\
Reverse primer & $5^{\prime}-A A A G T G A G G G C T G T A A G T T A T C G-3^{\prime}$ & \\
\hline
\end{tabular}

SRY; Sex determining Region Y

prophylactic gonadectomy soon after diagnosis. ${ }^{3)}$ We report here a case of Swyer syndrome with a brief review of literature.

\section{Case report}

A 34-year-woman presented to our hospital complaining of primary amenorrhea. Approximately 15 years earlier, she had been informed that she had a constitutional chromosomal abnormality, however she took no medical treatment at that time. When she presented at our hospital, she had a normal stature, scanty pubic and axillary hair, no breast development, and female external genitalia. A gynecological examination of the internal genitalia showed the presence of a normal uterus and vagina. Pelvic MRI revealed female internal genitalia with a small sized uterus and full vagina, but neither ovaries nor testes were detected. A hormonal profile revealed decreased estradiol levels $(<10 \mathrm{pg} / \mathrm{ml})$, elevated follicle stimulating hormone (FSH) levels up to $80.12 \mathrm{IU} / \mathrm{L}$ (reference range ; 0-25 IU/L) and luteinizing hormone (LH) levels up to $20.75 \mathrm{IU} / \mathrm{L}$

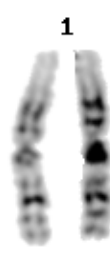

6
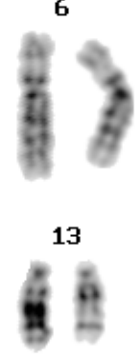

19

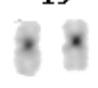

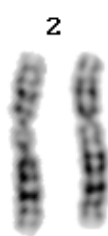
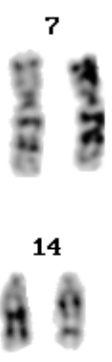

20

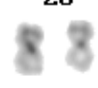

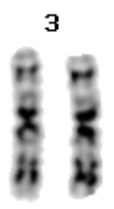
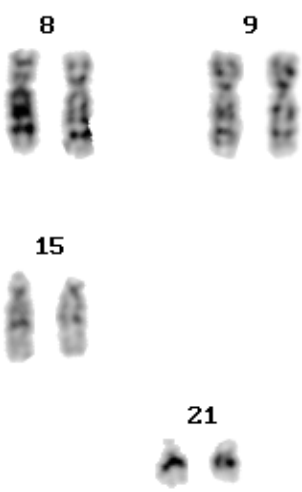
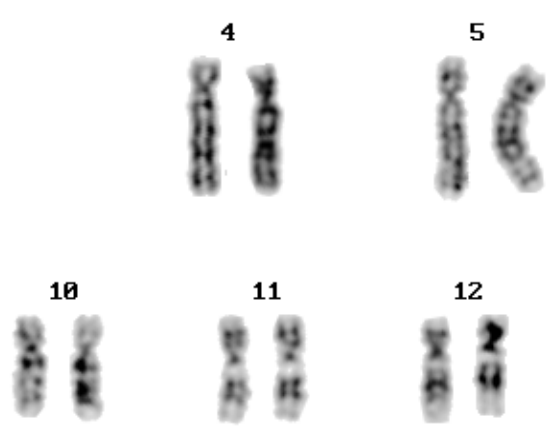

11
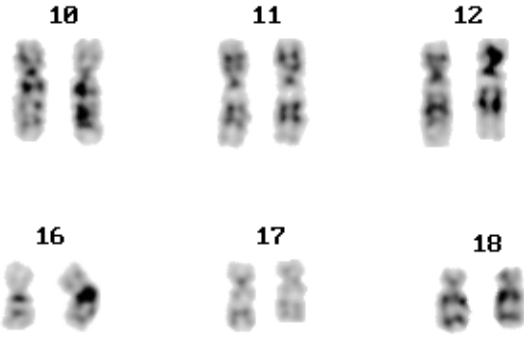

22

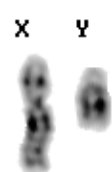

Fig. 1. The representative karyotype shows 46,XY. 
(reference range ; 0-20 IU/L). Testosterone level was $0.12 \mathrm{ng} / \mathrm{ml}$ (reference range for women ; $<0.8 \mathrm{ng} / \mathrm{mL}$ ) and prolactin level was $18.73 \mathrm{ng} / \mathrm{ml}$ (reference range for women ; $1-25 \mathrm{ng} / \mathrm{mL}$ ). Cytogenetic analysis was performed using the peripheral blood T-lymphocyte, and the karyotype was 46,XY (Fig. 1). We designed a set of primers for amplification of the entire Sex determining Region Y (SRY) gene (Table 1). In polymerase chain reaction (PCR) for the SRY gene, a single band was detected in $739 \mathrm{bp}$, as would occur for a normal male (Fig. 2). Direct sequencing of PCR product, revealed that the cytosine at nucleotide position 465 altered to thymine, but the serine at amino acid position 155 was not changed by this nucleotide alteration, indicating that single nucleotide polymorphism (SNP) had occurred. Laparoscopic salpingectomy and gonadectomy was carried

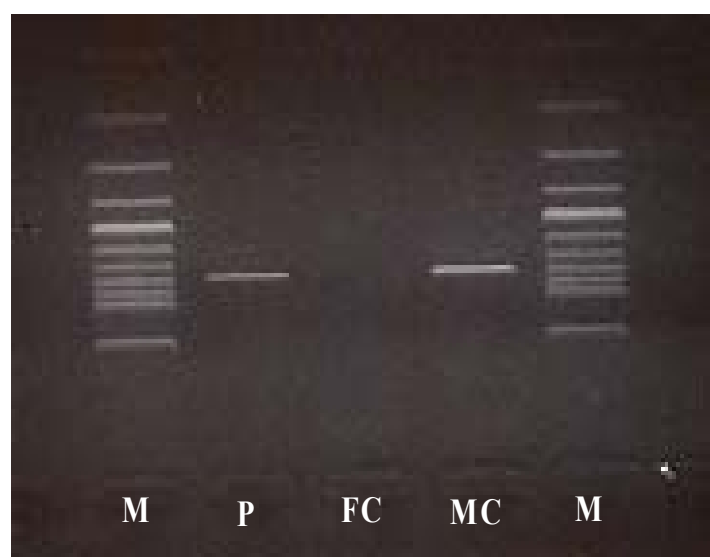

Fig. 2. Single band was detected in 739 bp in polymerase chain reaction for the SRY gene. SRY; Sex determining Region Y, M; size marker, $\mathrm{P}$; patient, $\mathrm{FC}$; female control, $\mathrm{MC}$; male control out and the histological examination of the gonad like lesions was consistent with gonadal dysgenesis, however no tumor cells were found. Estrogen replacement therapy was started.

\section{Discussion}

$46, \mathrm{XY}$ gonadal dysgenesis is characterized by abnormal testicular determination, ${ }^{4)}$ and the form of gonadal dysgenesis is determined based on the histology of the affected gonad. ${ }^{5)}$ Individuals with 46,XY pure gonadal dysgenesis (Swyer syndrome) lack testicular development and have bilateral streak gonads. Because they do not have testes, testosterone and antimullerian hormone $(\mathrm{AMH})$ are not produced. The Wolffian structures (seminal vesicles, vas deferens and epididymis) fail to develop due to lack of testosterone, however the Mullerian structures (uterus, fallopian tubes and upper third of the vagina) develop well without AMH. Individuals with 46,XY mixed gonadal dysgenesis have a streak gonad on one side and dysgenetic or normal appearing gonad on the other side. ${ }^{6,7)}$ Swyer syndrome, first described by Swyer in 1955, is a rare syndrome characterized by a female phenotype, normal to tall stature, eunuchoid with normal female external genitalia, hypoplastic uterus and fallopian tubes, bilateral dysgenetic gonads and sexual infantilism with primary amenorrhea. ${ }^{8)}$

The first step in the sexual differentiation 
- Soon Il Jung $\cdot$ Hee Soon Cho $\cdot$ Chae Hoon Lee $\cdot$ Kyung Dong Kim -

of a normal XY fetus is the testicular development. The early stage of testicular formation in the second month of gestation requires the action of several genes, of which one of the earliest and most important is the SRY gene. If the SRY gene absent, the fetal gonads develop as ovaries. In addition, the SRY gene plays a essential role in sex determination and testicular development. It is located on the short arm of the $\mathrm{Y}$ chromosome (Yp11), and consist of a single exon in which the central area of the open reading frame (ORF) encodes a 79 -aminoacid region with high similarity to a motif known as the high-mobility-group (HMG) box. ${ }^{9}$ HMG-box-containing protein has DNA-binding and DNA-bending activities and acts as a transcriptional regulator. Altered SRY sequence has been reported in 15 20\% of the cases of 46,XY gonadal dysgenesis, ${ }^{10}$ most of which occur in the HMG box, leading to alteration of the DNA-binding and DNA-bending activity, which is essential in the induction of testicular development by the SRY protein. ${ }^{11)}$ However, mutation of the SRY gene has not detected in many patients with Swyer syndrome, including the one evaluated in our case. Therefore, there may be another unknown genetic locus that is involved in the testicular development. To date, two other chromosomal regions have been implicated in XY sex-reversal without additional malformations: the subtelomeric region of the short arm of chromosome 9 and the dosage sensitive sex reversal (DSS) locus on the short arm of the X chromosome. ${ }^{12)}$

Germ cell tumors, including gonadoblastoma and dysgerminoma, occur in $20 \sim 30 \%$ of the patients who have gonadal dysgenesis and the $\mathrm{Y}$ chromosome. The presence of mutations in the SRY gene is highly related to the presence of germ cell tumors in pure $\mathrm{XY}$ sex-reversal patients, ${ }^{13)}$ however a recent study described an XY female with dysgerminoma and no mutation in the coding region of the SRY gene. ${ }^{14)}$ The results of these reports suggest that SRY is one of several genes involved in the initiation of gonadal neoplasm, and detection of mutations in the SRY gene alone cannot predict the presence of gonadal tumors. In addition, it seems that the presence of a malignancy is related to the age of the patient. The incidence of germ cell tumors increases to $50 \sim 70 \%$ in the third decade of life and to $80 \%$ at 40 years of age. The increasing incidence suggests that additional mutations of genes other than SRY occur with advancing age. ${ }^{15)}$

Patients diagnosed with Swyer syndrome should undergo prophylactic bilateral gonadectomy, followed by estrogen replacement therapy, which can induce secondary sexual characteristics.

\section{요 약}

$46, \mathrm{XY}$ 순수 생식선 이형성증은 여성의 표현 
형에 정상 혹은 큰 키를 가지며 원발성 무월경 과 성적 유치증을 보이고, 내부 생식기에 자궁 과 질이 존재하지만 양측 성선 이형성을 나타 내는 성전환(sex-reversal)질환의 일종이다. 성 선 이형성증과 $\mathrm{Y}$ 염색체를 가자는 환자의 20 $\sim 30 \%$ 에서 종양이 발생한다. 이차 성징이 결 여되어 있고 그 외의 다른 신체적 기형은 발견 되지 않은 34세 여성이 원발성 무월경을 주소 로 내원하였다. 말초혈액 핵형분석에서 $46, \mathrm{XY}$ 였고, 중합효소 연쇄반응(Polymerase Chain Reaction)에서 SRY(Sex Detetmining Region $\mathrm{Y})$ 유전자 양성으로, SRY 유전자 염기서열 분 석에서는 단일 염기 변이를 보였다. 복강경을 이용한 양측 성선제거술을 시행하였으며, 종양 세포는 발견되지 않았다. 수술 후 에스트로겐 대체 요법을 시행하였다.

\section{References}

1. Lee KO, Lee DH, Shin BS, Kim KH, Yoon MS. Two Cases of Swyer Syndrome in Sisters. Korean J Obstet Gynecol 2003 Oct;46(10): 2060-64.

2. Rebar RW. Puberty. In: Berek JS, editor. Berek \& Novak's Gynecology. 14th ed. Philadelphia: Lippincott Williams \& Wilkins; 2007. p.991-1034

3. Nam YS, Lee SH, Han JH, Cho SW, Yoon TK, Lee CN, et al. A Case of Swyer Syndrome Which showed a Positive SRY Gene in Peripheral Blood and Gonad. Korean J Fertil Steril 1999 Aug;26(2):275-80.

4. Berkovitz GD, Fechner PY, Zacur HW, Rock JA, Snyder HM 3rd, Migeon CJ, et al. Clinical and pathologic spectrum of 46,XY gonadal dysgenesis: Its relevance to the understanding of sex differentiation. Medicine (Baltimore) 1991 Nov;70(6):375-83.

5. Ostrer H. Sexual differentiation. Semin Reprod Med 2000;18(1):41-9.

6. Jawaheer D, Juo SH, Le Caignec C, David A, Petit C, Gregersen $\mathrm{P}$, et al. Mapping a gene for 46,XY gonadal dysgenesis by linkage analysis. Clin Genet 2003 Jun;63(6):530-5.

7. Robboy SJ, Miller T, Donahoe PK, Jahre C, Welch WR, Haseltine FP, et al. Dysgenesis of testicular and streak gonads in the syndrome of mixed gonadal dysgenesis: perspective derived from a clinicopathologic analysis of twenty-one cases. Hum Pathol 1982 Aug;13 (8):700-16

8. Swyer GI. Male pseudohermaphroditism: A hitherto undescribed form. Br Med J. 1955 Sep 17;2(4941):709-12.

9. Uehara S, Hashiyada M, Sato K, Nata M, Funato T, Okamura K. Complete XY gonadal dysgenesis and aspects of the SRY genotype and gonadal tumor formation. J Hum Genet 2002;47(6):279-84.

10. Brennan J, Capel B. One tissue, two fates: Molecular genetic events that underlie testis versus ovary development. Nat Rev Genet 2004 Jul;5(7):509-21.

11. Harley VR, Jackson DI, Hextall PJ, Hawkins JR, Berkovitz GD, Sockanathan S, et al. DNA binding activity of recombinant SRY from normal males and XY females. Science 1992 Jan 24;255(5043):453-6.

12. Kempe A, Engels H, Schubert R, Meindl A, van der Ven $\mathrm{K}$, Plath $\mathrm{H}$, et al. Familial ovarian dysgerminomas (Swyer syndrome) in females associated with 46,XY-karyotype. Gynecol Endocrinol 2002 Apr;16(2):107-11.

13. Berg FD, Kürzl R, Hinrichsen MJ, Zander J. Familial 46,XY pure gonadal dysgenesis and gonadoblastoma/dysgerminoma: Case report. 
- Soon Il Jung $\cdot$ Hee Soon Cho $\cdot$ Chae Hoon Lee $\cdot$ Kyung Dong Kim -

Gynecol Oncol 1989 Feb;32(2):261-7.

14. Morerio C, Calvari V, Rosanda C, Porta S, Gambini C, Panarello C. XY female with a dysgerminoma and no mutation in the coding sequence of the SRY gene. Cancer Genet Cytogenet 2002 Jul 1;136(1):58-61.
15. Iliopoulos D, Volakakis N, Tsiga A, Rousso I, Voyiatzis N. Description and molecular analysis of SRY and AR genes in a patient with 46,XY pure gonadal dysgenesis (Swyer syndrome). Ann Genet 2004 Apr-Jun;47(2):185-90. 